\title{
Deflation activity in the Begovitsa valley (Pirin Mountain)
}

\section{Дефлационна дейност в долината на р. Беговица (Пирин планина)}

\author{
Simeon Matev, Dimitar Krenchev, Rossitza Kenderova \\ Симеон Матев, Димитьр Кренчев, Росица Кендерова
}

Sofia University St. Kliment Ohridski, Faculty of Geology and Geography; Dept. Klimatology, Hydrology and Geomorphology;

E-mails: simovremeto@abv.bg; krenche@abv.bg; rosica@gea.uni-sofia.bg

\begin{abstract}
The article presents the results of deflation activity researches in the upper (2240 m a.s.l.) and lower (1760 m a.s.1.) part of Begovitsa river valley. For the purpose, data from Automatic Weather Station (AWS) and wind direction marks were used and analyzed. Wind roses were performed for both, upper and lower part of the river valley.
\end{abstract}

Keywords: deflation activity, wind rose, Begovitsa River, Automatic Weather Station, Pirin Mountain.

\section{Въведение}

Дейността на вятъра е най-слабо изследваната част от екзогенезата в страната ни и още помалко във високопланинската част на Пирин. В настоящата публикация анализьт на дефлационната дейност е направен на основата на данните, получени от автоматична метеорологична станция (AMC), разположена в района на х. Беговица (на 1760 m) - фиг. 1. Тя е от типа Davis Wireless Vantage Pro2. За архивиране на информацията е използван WeatherLink data logger. Обработените данни са за 4 годишен период (2018-2021 г.). Резултатите от станцията характеризират условията в горския пояс.

Над горната граница на гората, в ниската част на едноименния циркус беше оставен репер (по идея от методиката на Tolstih, Kljukin, 1984), ориентиран по 4-те основни посоки. За силата и посоката на вятъра се съди по броя и големината на ударите, нанесени върху повърхностите на 4-те стени.

Целта на изследването е да се анализират данните за вятьра по югозападния склон на планината като се направи сравнение на посоката му в горската зона и над горната граница на гората.

\section{Резултати}

Получените данни от метеостанция Беговица са обобщени за максималните и средни скорости на ветровете. Максималните скорости на вятьра $(20 \mathrm{~m} / \mathrm{s})$ са анализирани, защото те придвижват еолов материал с различни размери (напр. при скорости над $13 \mathrm{~m} / \mathrm{s}$ вятърът е в състояние да транспортира късове над 1,5 cm според Kukal, 1983). Данните от станцията показаха, че преобладаващата посока на ветровете с максимална скорост е северна и север-североизточна. Допускаме, че иглолистният пояс (височината на дърветата е повече от 10-15 m) в някаква степен изкривява посоката на вятъра и със сигурност оказва влияние върху скоростта му. Реалната роза на ветровете при всички измерени скорости също потвърди северната посока, но тук с поголямо участие са изток-североизточните и североизточните ветрове.

В циркусната част данните от репера показаха, че най-голямото количество от движещ се материал е в слоя между 30 и $50 \mathrm{~cm}$ над земната повърхнина. С близки по брой удари са източната (15 бр.) и северната страна на репера (13 бр.) И двете са в посока към склонове на върхове Яловарник $(2764 \mathrm{~m})$ и Зъбът $(2686 \mathrm{~m})$, и към рида Беговишки чукар $(2686 \mathrm{~m})$. В подножието на тези върхове са образувани значителни по размери срутищно-сипейни конуси. По брой удари следва и южната (10 бр.) страна, а по западната страна удари не са отбелязани. Западната е в посока към троговата долина и респ. към 


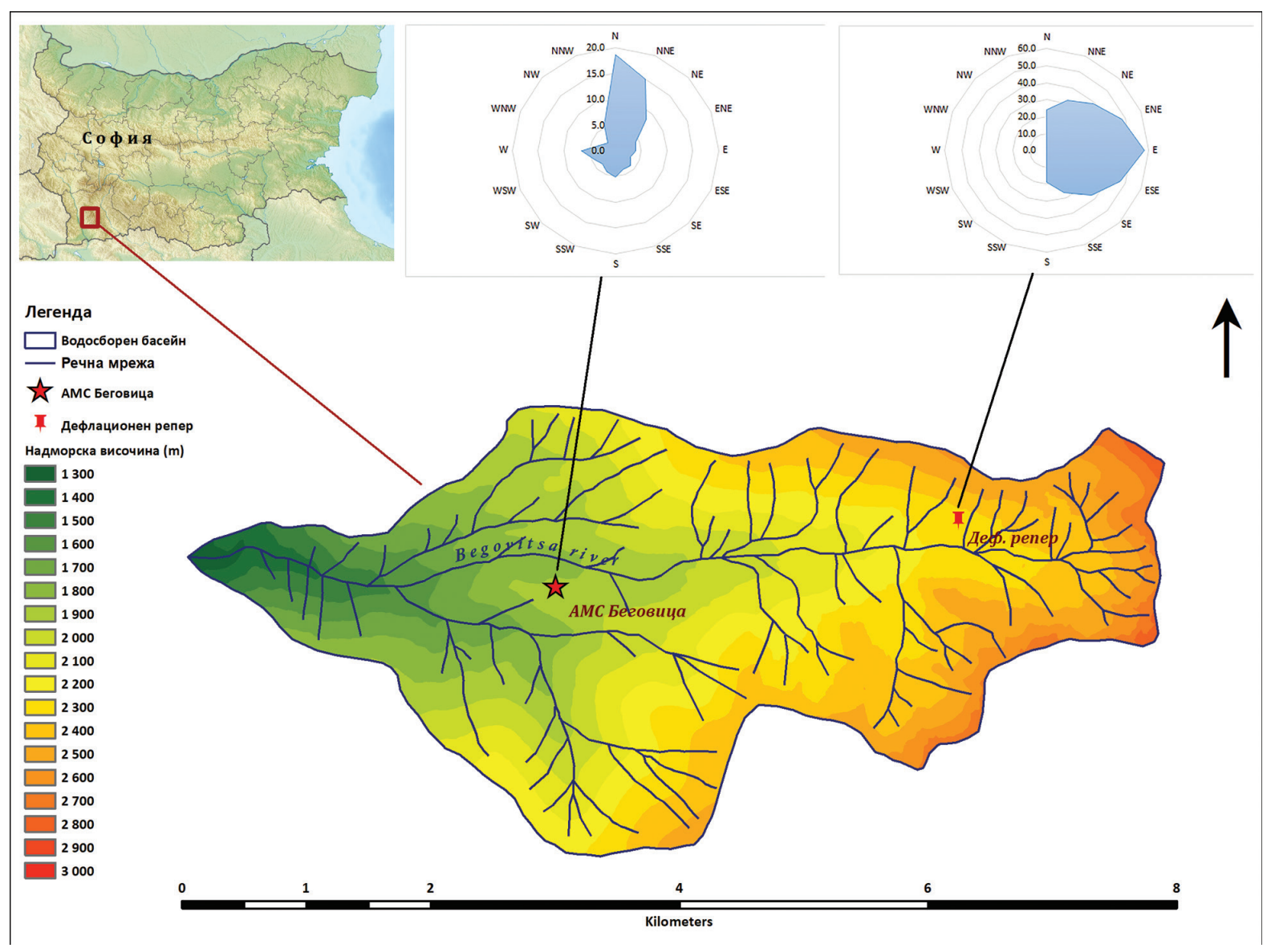

Фиг. 1. Долината на р. Беговица и рози на ветровете в изследваните участъци

горския пояс и това е причината за по-малкия брой. Най-големите по размери удари са по северната страна (по осите „х““ и „у“ те са $2 / 3 \mathrm{~cm}$ ), следвани от североизточната, източната, южната и западната. Общо средните размери (по осите ,х“" и ,у“') са 0,5/0,4 cm.

\section{Заключение}

Местоположението на долината на р. Беговица е в направление запад-изток и теоретично би следвало това да обуслови повече ветрове със западна компонента, следвани от тези с източна и северна. Измерените обаче реални посоки са резултат от особеностите на склона, на който е разположена станцията в района на х. Беговица. Той е по-широко отворен на север и изток и е заслонен на юг и в по-малка степен на запад. Река Беговица тече северно от хижата и това допълнително увеличава случаите на вятър със северна компонента. Тези ветрове са част от планинско-долинната циркулация, характерна за високопланинския пояс.

В горския пояс и този над горната граница на гората, ветровете с максимална скорост и всички други имат преобладаваща посока север и север-североизток. Над пояса на гората обаче тя се конкурира с източната и причината затова не е само в експозицията на склоновете, а и в това, че на тази височина посоката кореспондира с общата атмосферна циркулация.

Ветровете са в състояние да придвижат късове с размери до 2-3 cm. Най-много късове с разнообразни размери се движат в слоя 30-50 cm над земната повърхност. Източници за него се явяват денудационните склонове на циркусите, срутищно-сипейните конуси и шлейфове в подножията им, както и повърхността на разрушаващите се едри блокове.

Благодарности: Настоящото изследване е част от мониторинговата дейност по изпълнението на проект към ФНИ на МОН „Природната среда в Пирин планина в условията на климатични промени“ Договор № 14/6, 13.12.2017.

\section{Литература \\ Reference}

Tolstih E., A. Kljukin. 1984. Metodika Izmerenia Kolichestvenih Parametrov Ekzogennih Geologicheskih Protsessov. Moscow, 117 p. (in Russian).

Kukal, Z. 1983. Skorost Gologicheskih Protsessov. Moscow, 248 p. (in Russian). 